\title{
Cadmio complexes with biological activity: Scientific and technological prospection
}

\author{
Complexos de cádmio com atividade biológica: Prospecção científica e tecnológica \\ Complejos de cadmio con actividad biológica: Prospección científica y tecnológica
}

Received: 04/17/2021 | Reviewed: 04/25/2021 | Accept: 04/28/2021 | Published: 05/07/2021

\author{
Ruan Sousa Bastos \\ ORCID: https://orcid.org/0000-0003-3585-1596 \\ Universidade Federal do Pará, Brazil \\ E-mail: sonruanquimica@gmail.com \\ Joabe Lima Araújo \\ ORCID: https://orcid.org/0000-0002-4806-9192 \\ Universidade de Brasília, Brazil \\ E-mail: joabearaujobiotec@gmail.com \\ Vitória Santos Azevedo \\ ORCID: https://orcid.org/0000-0002-0607-7397 \\ Universidade Federal do Maranhão, Brazil \\ E-mail: azevedov614@gmail.com \\ Maria de Lourdes de Aguiar Silva Ferreira \\ ORCID: https://orcid.org/0000-0002-1964-7926 \\ Universidade Federal do Maranhão, Brazil \\ E-mail: lurdes.mdlf8@gmail.com \\ Lúcio Rocha de Lima \\ ORCID: https://orcid.org/0000-0002-2187-6154 \\ Universidade Federal do Pará, Brazil \\ E-mail: luciorolima@gmail.com \\ Jefferson Almeida Rocha \\ ORCID: https://orcid.org/0000-0001-6619-2293 \\ Universidade Federal do Maranhão, Brazil \\ E-mail: jeffersonbiotec@gmail.com
}

\begin{abstract}
Cadmium is a toxic metal from 12th group and 5th period of the periodic table. It's common its use in batteries manufacturing and metal alloys production. It is absorbed by the organism of animals and plants causing risks to human health by bioaccumulation. Even with proven levels of toxicity, complexes involving this atom have biological activity according to several studies. As a study methodology, data were prospected in different databases for patents and the scientific papers published in the period up 1962 to 2021 . Only 3 patents were found regarding the biological activity of complexes containing cadmium, although 3.257 results have been found for Cd (II) articles. The database with the highest number of published articles was Scifinder with 63\% (2.037) of the articles. Few articles approached anthelmintic activity, showing that future research related to chemical substances containing this metal is a possibility in the new anthelmintic drugs investigation.
\end{abstract}

Keywords: Cadmium; Prospection; Biological activity.

\section{Resumo}

O cádmio é um metal tóxico do $12^{\circ}$ grupo e $5^{\circ}$ período da tabela periódica. É comum seu uso na fabricação de baterias e produção de ligas metálicas. É absorvido pelo organismo de animais e plantas causando riscos à saúde humana por bioacumulação. Mesmo com níveis comprovados de toxicidade, complexos envolvendo esse átomo apresentam atividade biológica de acordo com diversos estudos. Como metodologia de estudo, foram prospectados dados em diferentes bases de dados de patentes e artigos científicos publicados no período de 1962 a 2021. Apenas 3 patentes foram encontradas referentes à atividade biológica de complexos contendo cádmio, embora tenham sido encontrados 3.257 resultados para Cd (II) artigos. A base de dados com maior número de artigos publicados foi Scifinder com 63\% (2.037) dos artigos. Poucos artigos abordaram a atividade anti-helmíntica, mostrando que pesquisas futuras relacionadas a substâncias químicas contendo esse metal são uma possibilidade na investigação de novos antihelmínticos.

Palavras-chave: Cádmio; Prospecção; Atividade biológica.

\section{Resumen}

El cadmio es un metal tóxico del $12^{\circ}$ grupo y el $5^{\circ}$ período de la tabla periódica. Es común su uso en la fabricación de baterías y la producción de aleaciones metálicas. Es absorbido por el organismo de animales y plantas provocando riesgos para la salud humana por bioacumulación. Incluso con niveles probados de toxicidad, los complejos que 
involucran a este átomo tienen actividad biológica según varios estudios. Como metodología de estudio, se prospectaron datos en diferentes bases de datos de patentes y artículos científicos publicados en el período comprendido entre 1962 y 2021. Solo se encontraron 3 patentes sobre la actividad biológica de complejos que contienen cadmio, aunque se han encontrado 3.257 resultados para Cd (II) artículos. La base de datos con mayor número de artículos publicados fue Scifinder con el 63\% (2.037) de los artículos. Pocos artículos abordaron la actividad antihelmíntica, mostrando que la investigación futura relacionada con sustancias químicas que contienen este metal es una posibilidad en la investigación de nuevos medicamentos antihelmínticos.

Palabras clave: Cadmio; Prospección; Actividad biológica.

\section{Introduction}

During the 20th century, emerged in the scientific community the first version of the periodic table was developed by the chemist Mendeleev, with 60 elements and their properties. Currently, it is one of the most used tools in the chemist's daily life, as it brings several information about the elements as study support material for different areas, such as physics and biology, facilitating the interdisciplinarity of studies (Leite \& Porto, 2015; Lemes \& Pino Júnior, 2008).

The first report on the discovery of the cadmium element was made by the German chemist Friedrich Strohmeyer, from the University of Göttingen in 1817, due to an impurity found in zinc carbonate. It was then characterized and classified and is located in family 12, in period 5 of the periodic table, presenting a condensed electronic configuration [Kr] $4 \mathrm{~d} 105 \mathrm{~s} 2$. Its most notable physical characteristic is the silvery white color with a bluish hue on the surface.

Even though it is considered a rare metal, it is possible to find it in the earth's crust $(0.15 \mathrm{ppm})$ and in the sea, but its most common form is found in zinc sulfides, due to its instability. Concisely, almost all commercially produced cadmium is obtained as a by-product of refining a mineral composed of zinc sulfide, the sphalerite (Sharma et al., 2015; H. Zhang \& Reynolds, 2019).

The main use of this element occurs in the nickel-cadmium rechargeable battery industries (83\% of production), screens pigments, metal alloys and in factories. It has high toxicity values, causing serious health problems to human beings, as it has bioaccumulation properties, agglomerating in the organism of plants and animals, even under low concentrations. The main form of exposure that humans have to this metal is due to inhalation or ingestion (Caini et al., 2018; H. Zhang \& Reynolds, 2019; J. Zhang et al., 2019).

The ease with which this metal is absorbed into organisms and the disruption of physiological functions caused by it make it very dangerous (Płachetka-Bożek et al., 2018). Its direct contact causes the destruction of cells that react with oxygen in the main animal and plant organisms. Its absorption in plants occurs through the roots, which removes it from the contaminated soil (Wiangkham \& Prapagdee, 2018; Xin et al., 2019).

There are several cadmium complexes studied in terms of their biological action, whether bacterial or parasitic. Many researchers already use structures with metals to evaluate their possible biological activities, complex containing Zinc (Zn) (Burlov et al., 2018), Cobalt (Co) and Chromium (Cr) (Zong et al., 2019), Nickel (Ni) (Allab et al., 2020). Researchers synthesized structures with various metals and compare their effectiveness (Hassoon et al., 2020). Araújo et al. (2020) and Rocha et al. (2018) also studied a biological activity of Ruthenium (Ru) a heavy metal and in toxic, proving its effectiveness as antileishmanial and antischistosoma, respectively.

The challenges to access scientific information are still very large, especially in countries that are not fully developed and do not speak English, as it is the case in Brazil. Despite that 54.42\% of the articles published in Latin America are from research developed by Brazilians researchers (Pereira et al., 2013), this demonstrates that little access to research is responsible for limiting the country's scientific development.

Scientific and technological prospection becomes important because it is a tool to analyze knowledge in specific areas in a clear and objective way, providing the current situation of productions already carried out in certain fields (Pereira et al., 
2013). It is the first step to be carried out during the development of scientific projects and research, mainly those that will generate as a result monographs, dissertations and theses, in order to verify whether the works developed are unpublished.

The study by means of scientific and technological prospection defines the general guidelines for the practice of innovative research. Prospection has two general meanings, first is focused on the present, based on historical evidence and the second on what can be predicted in the near future or not. In general, it focuses on the present and the past (Freitas \& Oliveira, 2013). Thus, this study aims to carry out a scientific and technological prospecting of articles and patents indexed in national (Brazil) and international databases that use cadmium complexes as a bioactive agent.

\section{Methodology}

The present scientific prospecting research was carried out in the national (Brazil) and international databases of scientific productions and in the patent banks for the survey of technological prospecting data according to the method described by Dos Santos Araújo et al. (2016). The data were prospected in January 2021, having analyzed the patent applications filed and the scientific papers published in the period up 1962 to 2021 . The results of searches that presented themes related to battery production or any other issue other than the biological action of cadmium were discarded.

To carry out technological prospecting, patent searches were carried out in the following databases: European Patent Office (EPO) (https://www.epo.org/), United States Patent and Trademark Office (USPTO) (http://patft.uspto.gov/), Derwent Innovations Index (DII) (https://clarivate.com/webofsciencegroup/solutions/webofscience-derwent-innovation-index/) and Instituto Nacional de Propriedade Intelectual (INPI) (https://busca.inpi.gov.br/pePI/jsp/patentes/PatenteSearchBasico.jsp), using as descriptor the words "Cadmium complex" AND "cytotoxicity" and "Cadmium complex" AND "antibacterial".

Scientific prospection was realized after searching the databases: Scientific Electronic Library Online (Scielo) (https://scielo.org/), Portal Regional da Biblioteca Virtual de Saúde (Bireme) (https://bvsalud.org/), National Center for Biotechnology Information (PubMed) (https://www.ncbi.nlm.nih.gov/), Thomson Reuters (Web of Science) (https://www.webofknowledge.com), group Elsevier (Scopus) (https://www.scopus.com/), Science Direct (https://www.sciencedirect.com/) and on the SciFinder platform (https://scifinder.cas.org).

In addition to these descriptors, the research also included the presence of some search resources, such as Boolean operators and quotation marks, so they could help you find as many documents as possible, but selectively. The descriptors used in the search were: "Cadmium complex" AND "cytotoxicity", "Cadmium complex" AND "antibacterial activity", "cadmium complex" AND "biological activity", "cadmium complex" and "antimicrobial activity" and "cádmium complex" AND "anthelmintic activity", considering all documents that presented these terms in the title and abstract.

\section{Results and Discussion}

\subsection{Technological Prospection}

The databases for patent applications presented only 3 results for patents that have the descriptors used. The only bases that presented these patents was the EPO with the descriptors "Cadmium complex" AND "cytotoxicity", the others presented only results related to the production of batteries that use the element cadmium as a component. These results were discarded because they did not address the theme related to research.

The patent number US5272142A presents the metal porphyrins known as potential agents in the inactivation or destruction of the human immunodeficiency virus (HIV) (Sessler et al. 1990). The patent by Yonglan et al. (2016) presents the preparation method and the application of the cadmium complex containing naphthylmethylcarboxyl and phenanthroline and the application of the cadmium complex in the preparation of antitumor drugs. A patent number WO2011132028A1 was also 
found related to the synthesis of a cadmium complex and biological activity against the malaria parasite Plasmodium falciparum (Kiremire, 2013).

In view of the few results found in patent searches on "biological activity in complexes with cadmium", it is observed how necessary and important studies and research on this subject are carried out. In this way, there would be an increase in the manufacture of patents, as well as a greater deepening in the knowledge of biological activity in complexes such as cadmium.

Studies that refer to metals are important because they allow a new line of studies and research to be developed by the scientific community interested in deepening the role and importance of metals in human health (Lippard, 2006). New innovations in this area include the preparation of therapeutic molecules that can be used as diagnostic agents or as therapeutic agents and include the potential application of metal ions as synthetic supports for the design of new drugs (Gray, 2003).

The low rate of publication of patent deposits on cadmium metal and its biological activity may be a reflection of the incentive policies that are in a way, without time to mature such research. It is possible to mention the case of the Law of innovation and the low investment of public and private companies in the investment of patents, in addition to the extensive processing time of the patent registration. Thus making it possible for researchers and companies to deposit patents in countries where acceptance is faster, making it so there is an unsatisfactory number of published patents, referring to cadmium and biological activity, in Brazil (Dos Santos Araújo et al., 2016).

Another important factor for the absence of patents is due to the toxic characteristic of the cadmium element. Despite many investigations with potentials, it is necessary to develop the structures to decrease its toxic levels, not to mention the bioaccumulation factor. Therefore, it is important to note that the metal has to be sufficiently reactive to bind to the biological target, but it cannot be in excess so that it is not removed by the many molecules it will find until it reaches the target site (Ahmad et al., 2006). Eventually, as mentioned earlier, metals trigger toxic effects, depending, among other factors, on their physical-chemical characteristics, so effective studies and research are extremely important and relevant (Benite, 2007).

Synthetic studies of metallopharmaceuticals are directly contributing to the increase in pharmacological chemotechniques, which can be tested, and drugs can be obtained for the treatment of a variety of diseases. Therefore, it is important to study whether it is possible to form new metal complexes, even if the elements are harmful to the organism, to analyze and develop drugs by the same methods, ultimately serving as a reference for future drugs (Rocha et al., 2011).

\subsection{Scientific Prospection}

For scientific articles, the results were quite different, presenting several articles that had the descriptors used, as shown in Table 1. The descriptor that presented the greatest results was "cadmium complex" AND "drug" with 1,161 results, followed by "cadmium complex" AND "biological activity" with 649. By further refining the search, 546 were obtained for "cadmium complex" AND "antibacterial activity", 477 results for "cadmium complex" AND "cytotoxicity" and 414 for "cadmium complex" AND "antimicrobial activity ". The descriptor with the least results found was the "cadmium complex" AND "anthelmintic activity", with only 10 results. 
Table 1. Results of Scientific Prospecting in Scielo, Web Science, Bireme, PubMed, Scopus, Science Direct and Scifinder databases.

\begin{tabular}{cccccccc}
\hline Descriptors & Scielo & Web Science & Bireme & PubMed & Scopus & Science Direct & Scifinder \\
\hline $\begin{array}{c}\text { "cadmium complex" and } \\
\text { "biological activity" }\end{array}$ & 0 & 6 & 2 & 8 & 23 & 243 & 367 \\
$\begin{array}{c}\text { "cadmium complex" and } \\
\text { "antimicrobial activity" }\end{array}$ & 0 & 11 & 1 & 7 & 12 & 106 & 277 \\
$\begin{array}{c}\text { "cadmium complex" and } \\
\text { "antibacterial activity" }\end{array}$ & 0 & 10 & 3 & 3 & 6 & 107 & 417 \\
$\begin{array}{c}\text { "cadmium complex" and } \\
\text { "anthelmintic activity" }\end{array}$ & 0 & 0 & 0 & 0 & 1 & 4 & 5 \\
$\begin{array}{c}\text { "cadmium complex" and } \\
\text { "cytotoxicity" }\end{array}$ & 0 & 8 & 2 & 15 & 1 & 196 & 255 \\
"cadmium complex" and & 0 & 7 & 16 & 32 & 1 & 389 & 716 \\
\hline "drug" & & & & & & & \\
\hline
\end{tabular}

Source: Authors.

The base with the highest number of published articles was Scifinder with 63\% $(2,037)$. This is because it is a base of information focused on specific subjects in the areas of chemistry, followed by Science Direct with 32\% $(1,045)$, Pubmed $2 \%$ (65). The Web Science, Bireme and Scopus databases presented only $1 \%$ of the articles found. The Scielo database did not present any published article that coincided with the descriptors used in the research (Figure 1).

Figure 1. List of articles by different bases.

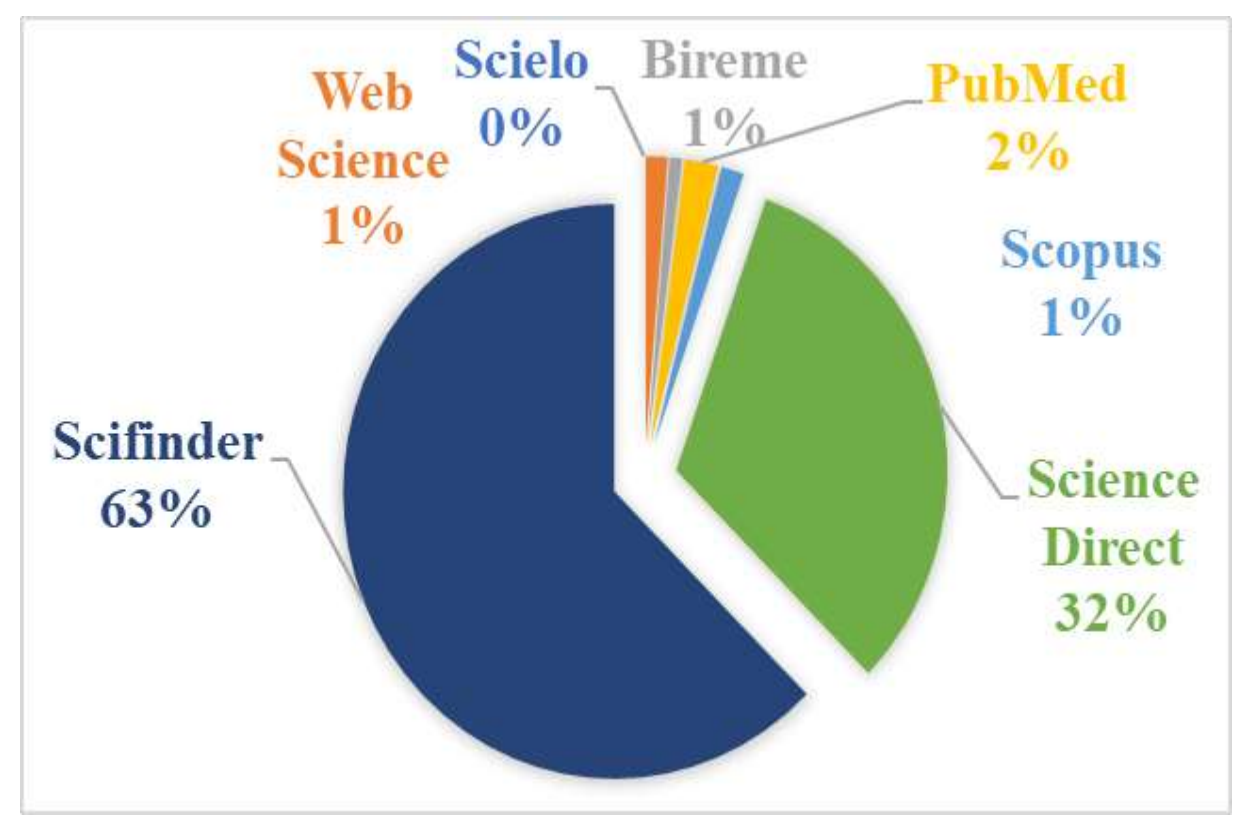

Source: Authors.

Studies containing biological activity of complexes with cadmium have evolved over the years. From the year 2010 onwards, there was an increase in the number of publications referring to them, and the base that presented the most published articles on biological activity was Scifinder, followed by Science Direct and Scopus. 2015 was the year with the highest number of publications, 27 (Scifinder), 16 (Science Direct), 2 (Scopus) and 1 (PubMed) as shown in Figure 2. 
Figure 2. Number of publications on "cadmium complex" and "biological activity" between the years 1962 to 2021 in Scielo, Web Science, Bireme, PubMed, Scopus, Science Direct and Scifinder databases.

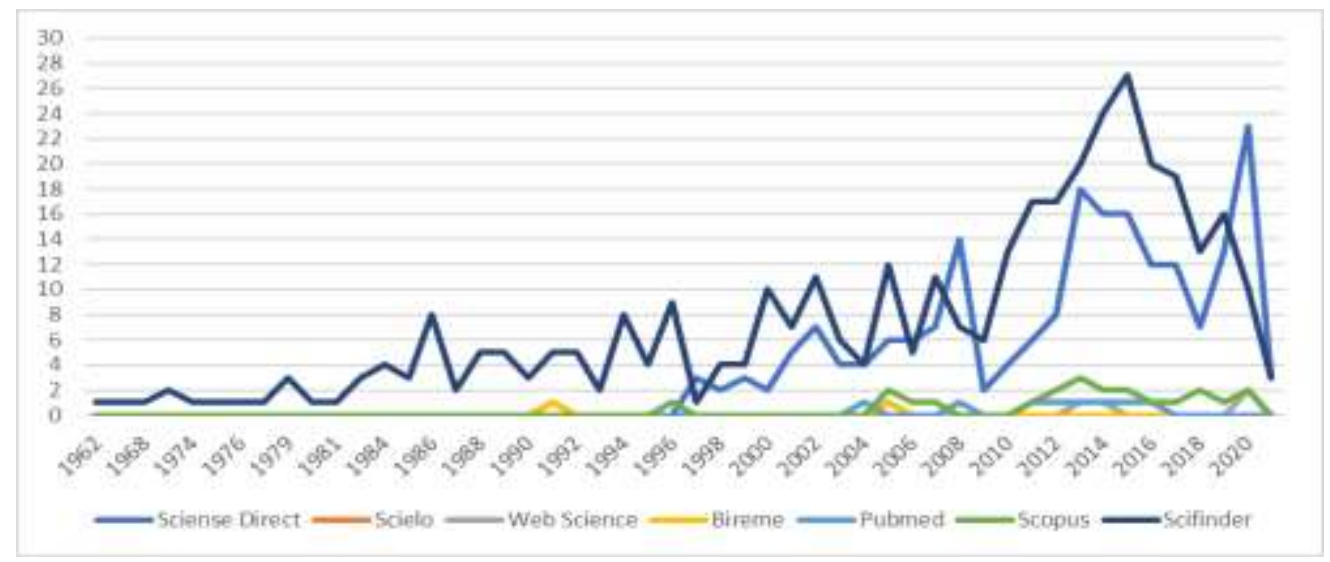

Source: Authors.

As we can see, there is still little research on cadmium complexes that have biological activity, especially those that deal with anthelmintic activity, one of the causes of neglected diseases. Most neglected diseases are caused by parasites, among which we can mention: Dengue, rabies, leprosy, leishmania and schistosomiasis. The current medications on the market are quite limited due to the lack of investment by the pharmaceutical industry and the increased biological resistance of parasitic strains (Dias et al., 2013). Thus, the search for new anthelmintics is important, and the investigation of cadmiumcontaining structures is valid considering the low number of drugs currently available.

\subsection{Biological activity and structure}

Bansal and Silakari (2012) described that 1,10- (1,3- propanediyl) bis-1H-benzimidazole has antimicrobial activity, pyridine-zaldehyde and 2-pyridyl-hydrazone with cadmium have great potential for biological study (Singh et al., 1982). The synthesis of a new complex 2-acetyl-2-thiazoline-thiosemicarbazone with cadmium (Figure 3) showed in studies of minimum inhibitory concentration (MIC) great activity against Staphylococcus epidermidis (12.4 mg/mL), Staphylococcus aureus (25 $\mathrm{mg} / \mathrm{mL})$, Enterococcus faecalis $(50 \mathrm{mg} / \mathrm{mL})$ and Escherichia coli $(25 \mathrm{mg} / \mathrm{mL})$ compared to complexes synthesized with other cobalt, zinc and nickel metals. Despite obtaining promising results, the S. epideermides and B. subtilis tests were inferior to the comparison antibiotic, ampicillin (Viñuelas-zahínos et al., 2011).

Figure 3. Crystal structure of the 5 (A) and 6 (B) complex of with proven antibacterial activity.

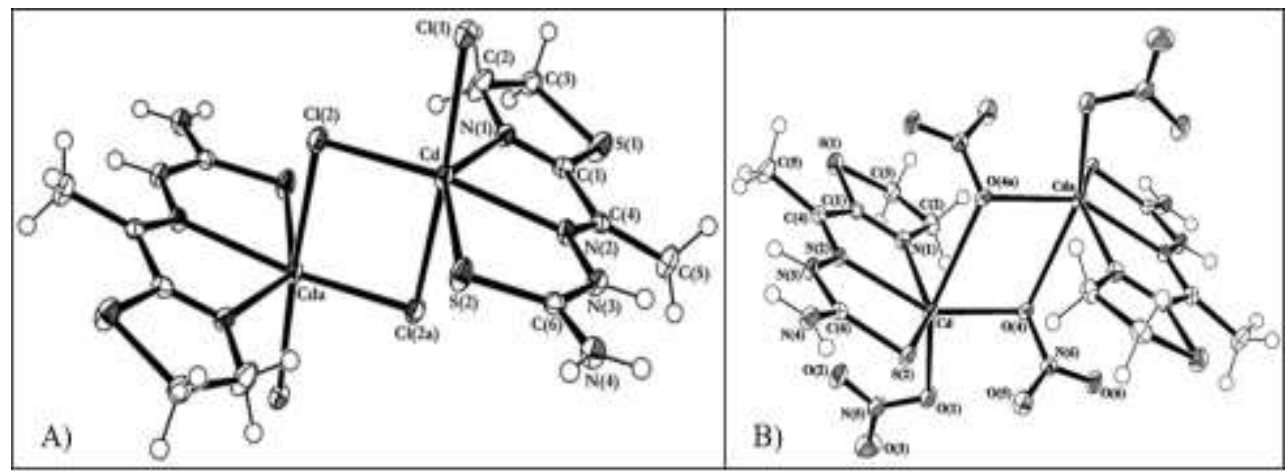

Source: Viñuelas-Zahínos et al. (2011).

The di-cationic complex of tetra-caffeine with cadmium (Figure 4) showed good antimicrobial results against $S$. 
aureus. Demonstrating, through molecular docking, a good affinity with the PI3Ky receptor responsible for several cellular processes that initiate the progression of cancer cells (Hamdani \& Amane, 2019). Although there are many published articles on antibacterial activity involving cadmium complexes, there are also those on antifungal activity, such as the hexamethyltetraazacyclotetradecadiene cadmium complex (Figure 5), tested on Candida albicans and Aspergillus aculeatus fungi showing potential results for antifungal activity better than the antiseptic griseofulvin, obtaining growth inhibition between $6 \mathrm{~mm}$ to $80 \mathrm{~mm}$ (Biswas et al., 2014).

Figure 4. Structure of tetra-caffeine synthesis, where "M" is replaced by $\mathrm{Cd}$ (cadmium).

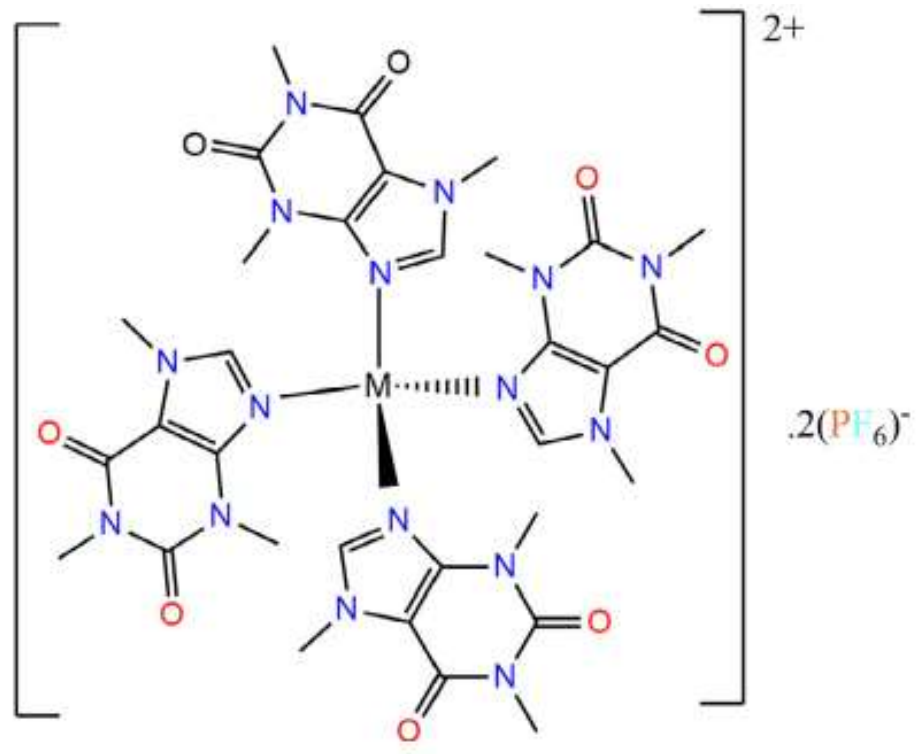

Source: Hamdani et al. (2019).

Figure 5. Complex structure $\left[\mathrm{Cd}(\right.$ theta $\left.) \mathrm{I}_{2}\right]$.

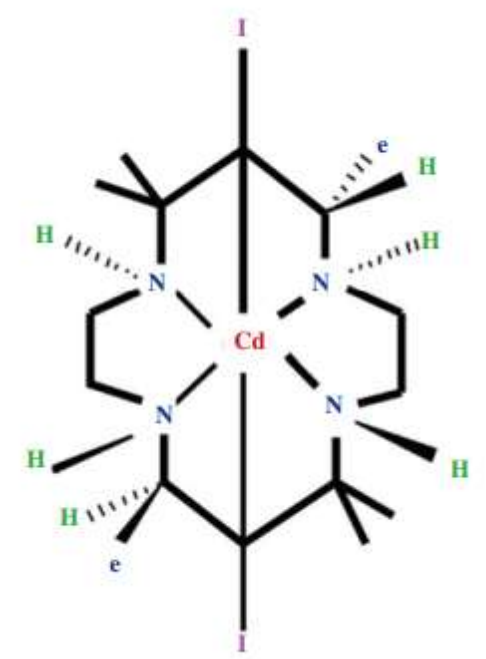

Source: Biswas et al. (2014).

The bacterial activity of cadmium was also tested with the anti-inflammatory drug diclofenac sodium with $\mathrm{Cd}(\mathrm{II})$ (Figure 6), showing great biological activity, where it was tested against three different types of human cancer cells, the MCF7 cell breast cancer, T24 bladder cancer cell and A-549 lung carcinoma. The results showed better cadmium complex activity 
when compared to the drug diclofenac alone. In that same research, antibacterial activity was performed, proving the inhibitory activity superior to the comparison compound (Tabrizi et al., 2015).

Figure 6. Structure of the cadmium complex synthesis with diclofenac.

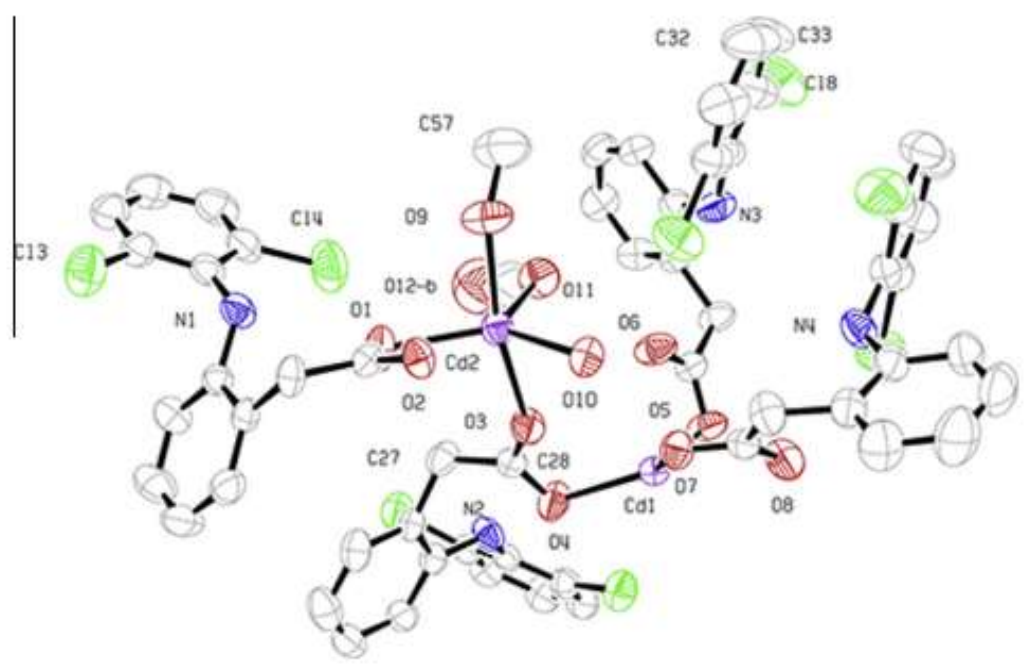

Source: Tabrizi et al. (2015).

The 1 - [(5-mercapto-1H-1,2,4-triazole-3-illimino) methyl] naphthalene-2-ol (HL1) and [(1H-O 1,2,4-triazole-3illimino) methyl] naphthalene-2-ol (HL2) (Figure 7) with cadmium were also characterized and studied with CT-DNA through molecular modeling study. It has been shown to have a good result of antitoxicity, anti-tumor activity and also antimicrobial activity compared to standard drugs. Antitumor activity occurred in HEPG2 cells known as liver cancer cells (Gaber et al., 2018).

Figure 7. Cadmium complex structure.

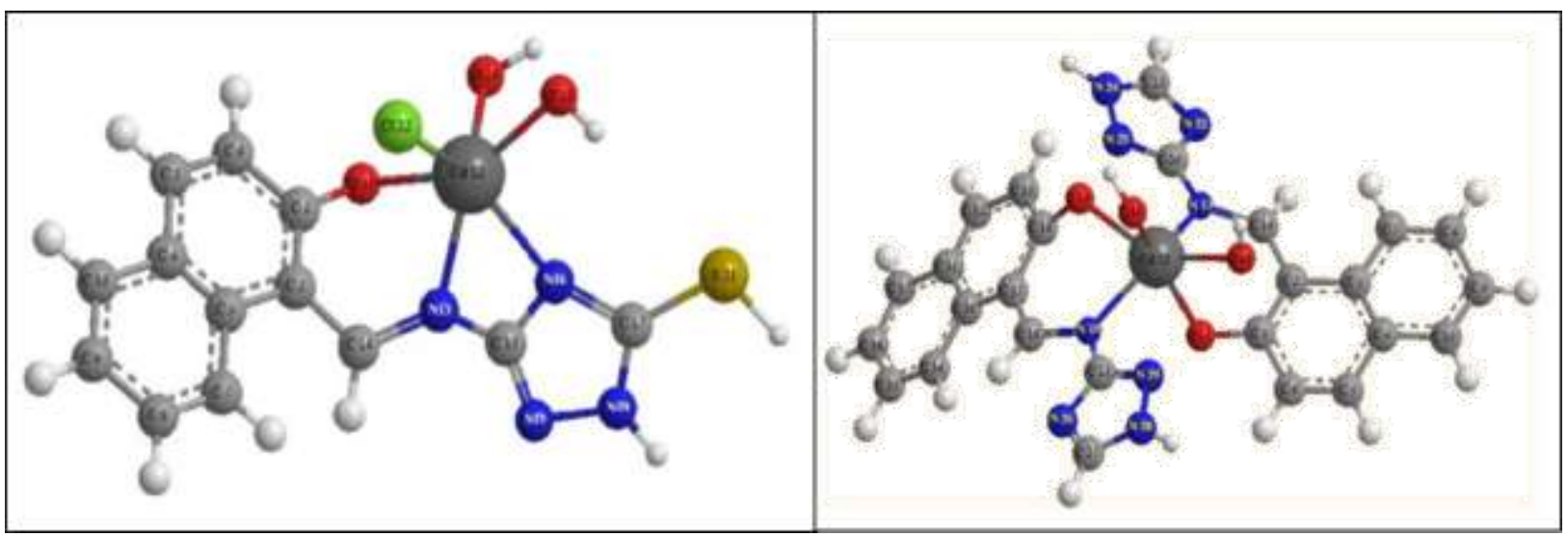

Source: Gaber et al. (2018).

Many factors contribute to the realization of tests to predict biological activities, among them the molecular modeling and molecular docking since they are in silico studies, facilitate the investigation process of the new complexes, saving time and laboratory resources, since the tests in vitro occur only after results that present favorable parameters for further investigations. Cadmium-containing compounds are not easy to synthesize, so it is important to start from a basic principle that there may be foundations for practical tests. 


\section{Conclusion}

Cadmium, even though it has high toxicity values, is still a promising target for scientific investigations, in addition to the many complexes synthesized without application, others are already used for biological tests in order to obtain structures with a high probability of antibacterial, antifungal activity, and even in research against tumor activity.

Even having only 3 patents filed, it is noticeable the large number of researches that relate this metal with biological activity. The low number of patents is due, precisely, to the difficulty of reducing toxicity to more acceptable levels, which has prevented their development, making this a challenge to be studied and developed methodologies that can help to reduce these high values.

There are still few articles dealing with the biological activity of cadmium, especially those that refer to anthelmintic articles published with complexes that present cadmium in its structure, thus demonstrating the possibility of future studies related to the use of chemical molecules containing this metal in the search for new anthelmintic drugs.

Future more in-depth studies, theoretically and experimentally, can help to determine organometallic chemical structures that may have low toxicity and maintain the high biological value. Bioaccumulation factors should also be studied, in case the discovery of a structure with low toxicity and proven biological activity does not affect the long term, causing adverse effects to those expected.

\section{References}

Ahmad, S., \& Isab, A. A. (2006). A1i S, et a1. Perspectives in bioinorganie ehemisstr of some metal-based therapeutic agents lJj. Polyhedron, 25(7), 16331645. https://doi.org/10.1016/j.poly.2005.11.004

Allab, Y., Chikhi, S., Zaater, S., Brahimi, M., \& Djebbar, S. (2020). Impact of the functionalized tetrazole ring on the electrochemical behavior and biological activities of novel nickel (II) complexes with a series of tetrazole derivatives. Inorganica Chimica Acta, 504, 119436. https://doi.org/10.1016/j.ica.2020.119436

Araújo, J. L., Bastos, R. S., Santos, G. T., de Moraes Alves, M. M., Figueiredo, K. A., de Sousa, L. A., \& Rocha, J. A. (2020). Molecular docking and evaluation of antileishmania activity of a ruthenium complex with epiisopiloturine and nitric oxide. Journal of Biosciences and Medicines, 8(5), 42-53. https://doi.org/10.4236/jbm.2020.85005

Bansal, Y., \& Silakari, O. (2012). The therapeutic journey of benzimidazoles: a review. Bioorganic \& medicinal chemistry, 20(21), 6208-6236. https://doi.org/10.1016/j.bmc.2012.09.013

Benite, A. M. B. M. (2007). Considerações sobre a química bioinorgânica medicinal. Revista eletrônica de Farmácia, 4(2). https://doi.org/10.5216/ref.v4i2.3027

Biswas, F. B., Roy, T. G., Rahman, M. A., \& Emran, T. B. (2014). An in vitro antibacterial and antifungal effects of cadmium (II) complexes of hexamethyltetraazacyclotetradecadiene and isomers of its saturated analogue. Asian Pacific journal of tropical medicine, 7, S534-S539. https://doi.org/10.1016/S1995-7645(14)60286-8

Burlov, A. S., Vlasenko, V. G., Koshchienko, Y. V., Makarova, N. I., Zubenko, A. A., Drobin, Y. D., \& Garnovskii, D. A. (2018). Complexes of zinc (II) with N-[2-(hydroxyalkyliminomethyl) phenyl]-4-methylbenzenesulfonamides: synthesis, structure, photoluminescence properties and biological activity. Polyhedron, 144, 249-258. https://doi.org/10.1016/j.poly.2018.01.020

Caini, S., Bendinelli, B., Masala, G., Saieva, C., Lundh, T., Kyrtopoulos, S. A., \& Palli, D. (2018). Predictors of erythrocyte cadmium levels in 454 adults in Florence, Italy. Science of the total environment, 644, 37-44. https://doi.org/10.1016/j.scitotenv.2018.06.347

Dias, L. C., Dessoy, M. A., Guido, R. V., Oliva, G., \& Andricopulo, A. D. (2013). Doenças tropicais negligenciadas: uma nova era de desafios e oportunidades. Química Nova, 36(10), 1552-1556. https://doi.org/10.1590/S0100-40422013001000011

dos Santos Araújo, K., de Sousa, S. F., Sousa, A. A. A., da Silva, J. S., \& Rocha, J. A. (2016). Prospecção Científica E Tecnológica Da Dengue No Brasil E No Maranhão No Período De 1994 A 2014. Cadernos de Prospecção, 9(3), 337. https://doi.org/dx.doi.org/10.9771/S.CPROSP.2016.009.036

Freitas, J. E. F., \& Oliveira, L. G. (2013). A importância da prospecção para a orientação da pesquisa científica visando a inovação. Espacios, 34(2), 6. https://www.revistaespacios.com/a13v34n02/13340206.html

Gaber, M., El-Ghamry, H. A., Fathalla, S. K., \& Mansour, M. A. (2018). Synthesis, spectroscopic, thermal and molecular modeling studies of Zn2+, Cd2+ and UO22+ complexes of Schiff bases containing triazole moiety. Antimicrobial, anticancer, antioxidant and DNA binding studies. Materials Science and Engineering: C, 83, 78-89. https://doi.org/10.1016/j.msec.2017.11.004

Gray, H. B. (2003). Biological inorganic chemistry at the beginning of the 21st century. Proceedings of the National Academy of Sciences, 100(7), 3563-3568. https://doi.org/10.1073/pnas.0730378100 
Hamdani, H. E., \& Amane, M. E. (2019). Preparation, spectral, antimicrobial properties and anticancer molecular docking studies of new metal complexes [M (caffeine) 4](PF6) 2; $\mathrm{M}=\mathrm{Fe}$ (II), Co (II), Mn (II), Cd (II), Zn (II), Cu (II), Ni (II). Journal of Molecular Structure, 1184, 262-270. https://doi.org/10.1016/j.molstruc.2019.02.049

Hassoon, A. A., Harrison, R. G., Nawar, N., Smith, S. J., \& Mostafa, M. M. (2020). Synthesis, single crystal X-ray, spectroscopic characterization and biological activities of $\mathrm{Mn} 2+, \mathrm{Co} 2+, \quad \mathrm{Ni} 2+$ and $\mathrm{Fe} 3+$ complexes. Journal of Molecular Structure, $1203, \quad 127240$. https://doi.org/10.1016/j.molstruc.2019.127240

Kiremire, E. (2013). U.S. Patent Application No. 13/642,692. https://patents.google.com/patent/US20130109857A1/en

Leite, H. S., \& Porto, P. A. (2015). Análise da abordagem histórica para a Tabela Periódica em livros de Química Geral para o Ensino Superior usados no Brasil no século XX. Química Nova, 38(4), 580-587. https://doi.org/10.5935/0100-4042.20150064

Lemes, M. R., \& Pino Junior, A. D. (2008). Periodic table of the elements in the perspective of artificial neural networks. Química Nova, 31(5), 1141-1144. https://doi.org/10.1590/S0100-40422008000500040

Lippard, S. J. (2006). The inorganic side of chemical biology. Nature chemical biology, 2(10), 504-507. https://doi.org/10.1038/nchembio1006-504

Pereira, S. A., Alves, H. P., de Sousa, C. M., \& Costa, G. L. S. (2013). Prospecção sobre o conhecimento de espécies amazônicas-Inajá (Maximiliana maripa aublt.) E Bacaba (Oenocarpus bacaba mart.). Revista GEINTEC-Gestão, Inovação e Tecnologias, 3(2), 110-122. https://doi.org/https://doi.org/10.7198/geintec.v3i2.106

Płachetka-Bożek, A., Kafel, A., \& Augustyniak, M. (2018). Reproduction and development of Spodoptera exigua from cadmium and control strains under differentiated cadmium stress. Ecotoxicology and environmental safety, 166, 138-145. https://doi.org/10.1016/j.ecoenv.2018.09.016

Rocha, D. P., Pinto, G. F., Ruggiero, R., Oliveira, C. A. D., Guerra, W., Fontes, A. P. S., \& Pereira-Maia, E. C. (2011). Coordenação de metais a antibióticos como uma estratégia de combate à resistência bacteriana. Química Nova, 34(1), 111-118. https://doi.org/10.1590/S0100-40422011000100022

Rocha, J. A., Rego, N. C., Carvalho, B. T., Silva, F. I., Sousa, J. A., Ramos, R. M., \& Lima, F. C. (2018). Computational quantum chemistry, molecular docking, and ADMET predictions of imidazole alkaloids of Pilocarpus microphyllus with schistosomicidal properties. PloS one, 13(6), e0198476. https://doi.org/10.1371/journal.pone.0198476

Sessler, J. L., Hemmi, G. W., \& Murai, T. (1990). U.S. Patent No. 4,935,498. Washington, DC: U.S. Patent and Trademark Office. https://patents.google.com/patent/US5272142A/en

Sharma, H., Rawal, N., \& Mathew, B. B. (2015). The characteristics, toxicity and effects of cadmium. International journal of nanotechnology and nanoscience, $3, \quad 1-9 . \quad \mathrm{https}: / /$ www.researchgate.net/profile/Blessy-Mathew-4/publication/305778858_The_characteristics_toxicity_and_effects_of_ cadmium/links/57a19fe508aeb1604832e9d9/The-characteristics-toxicity-and-effects-of-cadmium.pdf

Singh, R. B., Jain, P., \& Singh, R. P. (1982). Hydrazones as analytical reagents: a review. Talanta, 29(2), 77-84. https://doi.org/10.1016/0039-9140(82)800246

Tabrizi, L., Chiniforoshan, H., \& McArdle, P. (2015). Synthesis, crystal structure and spectroscopy of bioactive Cd (II) polymeric complex of the nonsteroidal anti-inflammatory drug diclofenac sodium: antiproliferative and biological activity. Spectrochimica Acta Part A: Molecular and Biomolecular Spectroscopy, 136, 429-436. https://doi.org/10.1016/j.saa.2014.09.053

Viñuelas-Zahínos, E., Luna-Giles, F., Torres-García, P., \& Fernández-Calderón, M. C. (2011). Co (III), Ni (II), Zn (II) and Cd (II) complexes with 2-acetyl-2thiazoline thiosemicarbazone: Synthesis, characterization, X-ray structures and antibacterial activity. European journal of medicinal chemistry, 46(1), 150159. https://doi.org/10.1016/j.ejmech.2010.10.030

Wiangkham, N., \& Prapagdee, B. (2018). Potential of Napier grass with cadmium-resistant bacterial inoculation on cadmium phytoremediation and its possibility to use as biomass fuel. Chemosphere, 201, 511-518. https://doi.org/10.1016/j.chemosphere.2018.03.039

Xin, C., Chi, J., Zhao, Y., He, Y., \& Guo, J. (2019). Cadmium stress alters cytosine methylation status and expression of a select set of genes in Nicotiana benthamiana. Plant Science, 284, 16-24. https://doi.org/10.1016/j.plantsci.2019.03.021

Yonglan, F., Wujiu, J., Daizhi, K., Yaping, O., Yuxing, T., Jiangxi, Y., Fuxing, Z. \& Xiaoming, Z., 2016. Cadmium complex containing naphthyl methyl carboxyl and phenanthroline and preparation method and application of cadmium complex. CN106317090A.

Zhang, H., \& Reynolds, M. (2019). Cadmium exposure in living organisms: A short review. Science of the Total Environment, 678, 761-767. https://doi.org/10.1016/j.scitotenv.2019.04.395

Zhang, J., Li, Q., Zeng, Y., Zhang, J., Lu, G., Dang, Z., \& Guo, C. (2019). Bioaccumulation and distribution of cadmium by Burkholderia cepacia GYP1 under oligotrophic condition and mechanism analysis at proteome level. Ecotoxicology and environmental safety, 176, 162-169. https://doi.org/10.1016/j.ecoenv.2019.03.091

Zong, X. J., Liu, X. R., Zhao, S. S., \& Yang, Z. W. (2019). Preparation, thermal analyses and biological activities of Co (II) and Cr (III) complexes with 2acetylpyridine-6-bromo-2-naphthoyl acylhydrazone. Polyhedron, 170, 303-311. https://doi.org/10.1016/j.poly.2019.05.059 